\section{PENGARUH TINGKAT PENDIDIKAN, UMUR, JUMLAH TANGGUNGAN KELUARGA, PENDAPATAN SUAMI DAN MOTIVASI TERHADAP KEPUTUSAN WANITA UNTUK BEKERJA DI KECAMATAN KOTO SALAK KABUPATEN DHARMASRAYA}

\author{
Bela Aulia Epinda, Ansofino, Putri Meliza Sari \\ Program Studi Pendidikan Ekonomi, STKIP PGRI Sumatera Barat \\ belaauliaepinda@gmail.com
}

\begin{abstract}
This study aims to analyze 1) the effect of education level, 2) the effect of age, 3) the influence of the number of family dependents, 4) the influence of husband's income and 5) the influence of motivation on women's decisions to work in Koto Salak District, Dharmasraya Regency. This research is focused on the influence of education level, age, number of dependents, husband's income and motivation on women's decision to work in Koto Salak Subdistrict, Dharmasraya Regency. The research method uses descriptive method. The results of the study show that: It can be seen that the results obtained are statistical> F table or $8.84>2.38$, so the decision $\mathrm{H} 0$ is rejected and $\mathrm{Ha}$ is accepted. So the variables of education level, age, number of family dependents, husband's income, motivation together have a significant effect on women's decisions to work.
\end{abstract}

Keywords: The Effect, Education Level, Women's Decision, Multinominal Logit

\section{PENDAHULUAN}

Seiring dengan perkembangan zaman dan era globalisasi yang semakin maju,kini wanita Indonesia diberi kesempatan serta peran yang sama dengan pria untuk berpartisipasi dalam pembangunan nasional. Peranan wanita sebagai mitra yang sejajar dengan pria pada saat ini bukan merupakan suatu hal yang baru. Hal tersebut telah diakui oleh pemerintah sejak masuknya peranan wanita dalam pembangunan yang telah tersirat dalam lima falsafah dasar bangsa Indonesia, yaitu Pancasila, Undang- Undang Dasar 1945, dan Garis-Garis Besar Haluan Negara Hastuti (2006) oleh karena itu wanita memiliki kesempatan untuk berpartisipasi dalam pembangunan di 
PENDIDIKAN

Publish by: Library of STKIP PGRI Sumatera Barat

E-ISSN : 2775-5770

Vol. 1 No. 2 (Mei 2021) (263-272)

http://ejournal.stkip-pgri-sumbar.ac.id/index.php/horizon

segala bidang, baik ekonomi, sosial, jasa yang pertama adalah tingkat dan budaya.

pendidikan. Tingkat pendidikan

Fenomena wanita bekerja sebenarnya sudah tidak asing lagi kita merupakan salah satu faktor yang dengar dan perhatikan dimasyarakat kita. Secara normatif pria aktif dalam kegiatan mencari nafkah, wanita adalah pekerja rumah tangga, namun fakta di lapangan ternyata perempuan disamping melakukan pekerjaan rumah tangga juga aktif dalam mencari nafkah. dapat mempengaruhi keputusan wanita untuk bekerja di sektor pertanian. Terutama bagi wanita yang memiliki pendidikan yang rendah, mereka akan memilih untuk bekerja di sektor pertanian karena bekerja di sektor pertanian tidak membutuhkan pendidikan tinggi.

Faktor yang kedua

Meningkatnya tenaga kerja mempengaruhi keputusan seorang wanita dalam kegiatan mencari wanita untuk bekerja adalah nafkah karena tersedianya lapangan kerja yang mudah dimasuki oleh wanita seperti bertani, usaha dagang, pembantu rumah tangga maupun pekerjaan dalam industri rumah tangga khususnya, industri rumah tangga tergolong masih usaha sederhana dan tradisional dan jika ditinjau dari modal yang dikeluarkan tidak terlalu besar untuk memulai suatu usaha tersebut.

Ada beberapa hal yang mempengaruhi wanita untuk bekerja di sektor pertanian, perdagangan dan Usia/Umur. Umur adalah salah satu faktor yang berpengaruh terhadap peningkatan pendapatan rumah tangga. Dari gambar tersebut dapat kita lihat pada usia 15-19 tahun jumlah laki-laki yang bekerja di Kecamatan Koto Salak sebanyak 340 jiwa sementara jumlah laki laki yang bekerja sebanyak 358, pada usia produktiv yaitu kisaran usia 20-39 tahun jumlah penduduk laki-laki dan perempuan yang memutuskan untuk bekerja semakin banyak, seperti kita lihat pada usia 30-34 tahun jumlah 
laki-laki yang bekerja sebanyak 485 jiwa, sementara jumlah penduduk wanita yang bekerja sebanyak 505 jiwa.

Faktor ketiga yang mempengaruhi keputusan wanita untuk bekerja adalah jumlah tanggungan keluarga. Jumlah tanggungan keluarga dapat menjadi salah satu alasan tenaga kerja wanita memutuskan untuk bekerja atau tetap berada dirumah menjalankan peran domestiknya.

Faktor keempat yang mempengaruhi keputusan seorang wanita untuk bekerja adalah tingkat pendapatan suami. Pendapatan keluarga, khususnya tingkat pendapatan suami sangat memegang peranan penting dalam keputusan wanita untuk masuk dalam pasar tenaga kerja, jika pendapatan suami masih belum mampu mencukupi kebutuhan keluarga, maka istri akan bekerja lebih banyak untuk membantu memenuhi kebutuhan rumah tangga

Faktor kelima yang mempengaruhi keputusan wanita berstatus menikah untuk bekerja adalah motivasi. Motivasi adalah kekuatan yang mendorong seseorang karyawan untuk menimbulkan dan mengarahkan perilaku individu. Sehingga semakin besar motivasi yang dimiliki oleh individu sebagai karyawan dapat meningkatkan prestasi kerja yang lebih baik.

\section{METODE PENELITIAN}

Sesuai dengan identifikasi masalah, perumusasn, dan tujuan penelitian, maka penelitian ini tergolong penelitian deskriptif dan asosiatif dengan pendekatan kuantitatif, karena penelitian ini menerangkan suatu gejala, peristiwa atau kejadian yang telah terjadi, serta menentukan ada atau tidaknya pengaruh suatu variabel bebas terhadap variabel terikat dimana hasil penelitian ini dinyatakan dalam bentuk angka. Menurut Arikunto (2010) penelitian deskriptif adalah penelitian yang dimaksudkan untuk mengumpulkan informasi mengenai status suatu gejala yang ada, yaitu 
keadaan gejala menurut apa adanya pada saat penelitian dilakukan.

Penelitian Asosiatif menurut Sangadji (2010) adalah suatu penelitian yang bertujuan mengetahui hubungan antara dua variabel lebih dan penelitina kuantitatif adalah penelitian yang datanya dinyatakan dalam angka dan dianalisis dengan teknik statistik

Penelitian ini dilaksanakan pada bulan agustus tahun 2020. Penelitian ini dilakukan di Kecamatan Koto Salak Kabupaten Dharmasraya

Populasi menurut Arikunto, (2010:173) adalah keseluruhan subjek penelitian.Adapun populasi dalam penelitian ini adalah Jumlah penduduk wanita yang bekerja di Kecamatan Koto Salak sebanyak 4235 orang

\section{HASIL DAN PEMBAHASAN}

Sampel menurut Arikunto (2010:174) adalah sebahagian atau Tabel 1. Hasil Analisis Regresi Linear Berganda Secara Keseluruhan

\begin{tabular}{lllllll}
\hline \multirow{2}{*}{ Model } & \multicolumn{3}{l}{$\begin{array}{l}\text { Jumlah Tanggungan } \\
\text { Keluarga Banyak }\end{array}$} & \multicolumn{4}{l}{$\begin{array}{l}\text { Jumlah Tanggungan Keluarga } \\
\end{array}$} & B & $\mathrm{T}$ & $\mathrm{S}$ Sig. & $\mathrm{B}$ & $\mathrm{T}$ & Sig. \\
\hline (Constant) & 3.319 & 3.895 & .000 & 2.248 & 1.747 & .109
\end{tabular}

266 | Bela Aulia Epinda, Ansofino, Putri Meliza Sari 1/ JHP, Vol. 1 No. 2, 2021 wakil populasi yang diteliti Sedangkan menurut Sugiyono (2014:62) sampel adalah bagian dari jumlah dan karakteristik yang dimiliki oleh populasi.

Penarikan sampel menggunakan Stratified Proportional Random Sampling atau Sampel berstrata. Jumlah sampel ini dibagi dalam satu Nagari Kecamatan Koto Salak dengan teknik bagi secara proporsional.

Pengambilan sampel dalam penelitian ini dikelompokkan berdasarkan jumlah tanggungan keluarga wanita yang memutuskan bekerja. Dimana dibagi menjadi dua yaitu jumlah tanggungan keluarga banyak dan jumlah tanggungan keluarga sedikit

Adapun hasil uji Analisi Linear Beganda dengan menggunakan bantuan program SPSS versi 16.0 dan eviews maka diperoleh data sebagai berikut 


$\begin{array}{lcccccc}\text { Tingkat Pendidikan } & .057 & .984 & .331 & .308 & 2.420 & .034 \\ \text { Umur } & .331 & -2.332 & .025 & .212 & 1.317 & .215 \\ \begin{array}{l}\text { Jumlah Tanggungan } \\ \text { Keluarga }\end{array} & .322 & 2.917 & .008 & -.198 & -1.175 & .265 \\ & & & & & & \\ \text { Pendapatan Suami } & -.230 & -1.821 & .076 & -.138 & -.811 & .435 \\ \text { Motivasi } & -.084 & -.556 & .581 & -.133 & -.589 & .567\end{array}$

Sumber: Olahan Data Primer, 2020

1. Pengaruh Tingkat Pendidikan Terhadap Keputusan Wanita Untuk Bekerja

Hasil penelitian di temukan terdapat pengaruh positif tingkat pendidikan terhadap peningkatan keputusan wanita untuk bekerja. Koefisien regresi tingkat pendidikan terhadap peningkatan keputusan wanita untuk bekerja, dimana nilai $\mathrm{t}$ hitung $\quad 0,669984$ dan nilai (prob $=0.5058>0,05$ ). Dengan $\mathrm{df}=60$ 6=54 diperoleh $\mathrm{F}_{\text {tabel }}$ Sebesar 1,674 dari hasil di atas dapat dilihat bahwa tingkat pendidikan berpengaruh terhadap keputusan wanita bekerja

Sumarsono (2005) yang menyatakan bahwa semakin tinggi tingkat pendidikan semakin banyak waktu yang disediakan untuk bekerja,terutama bagi perempuan, semakin tinggi pendidikan maka akan menjadikan waktu yang dimiliki menjadi mahal, dan keinginan untuk bekerja semakin tinggi, terutama bagi perempuan yang memiliki pendidikan tinggi, mereka akan memilih untuk bekerja daripada hanya tinggal dirumah untuk mengurus anak dan rumah tangga dengan semakin tinggi pendidikan kecenderungan untuk bekerja akan semakin besar.

Jadi dapat disimpulkan berdasarkan hasil penelitian yang dilakukan di Kecamatan Koto Salak Kabupaten Dharmasraya bahwa tingkat pendidikan berpengaruh terhadap keputusan wanita untuk bekerja.

2. Pengaruh Umur Terhadap Keputusan Wanita Untuk Bekerja

267 | Bela Aulia Epinda, Ansofino, Putri Meliza Sari 1/ JHP, Vol. 1 No. 2, 2021 
Vol. 1 No. 2 (Mei 2021) (263-272)

http://ejournal.stkip-pgri-sumbar.ac.id/index.php/horizon

Hasil penelitian di temukan terdapat pengaruh positif umur terhadap peningkatan keputusan wanita untuk bekerja. Koefisien regresi umur terhadap peningkatan keputusan wanita untuk bekerja, dimana nialai t hitung 1.259895 dan nilai (prob $=0,2133>0,05$ ). Dengan $\mathrm{df}=60-6=54$ diperoleh $\mathrm{F}_{\text {tabel }}$ Sebesar 1,674 dari hasil di atas dapat dilihat bahwa umur berpengaruh terhadap keputusan wanita bekerja.

Besamusca

mengungkapkan bahwa umur seseorang digolongkan menjadi umur produktif dan umur non produktif. Umur produktif berkisar antara 1564 tahun, sedangkan umur non produktif yaitu pada usia $<15$ tahun dan 65 tahun ke atas. Pada umur 1564 tahun merupakan umur ideal bagi para pekerja. Pada saat seseorang berada dalam golongan umur produktif, maka ia akan terus memaksimalkan tenaga dan waktu yang dimiliki untuk bekerja, sehingga mendapatkan pendapatan yang tinggi dan tergantung juga pada jenis pekerjaan yang dilakukannya.
Jadi dapat disimpulkan berdasarkan hasil penelitian yang dilakukan di Kecamatan Koto Salak Kabupaten Dharmasraya bahwa umur berpengaruh terhadap keputusan wanita untuk bekerja.

3. Pengaruh Jumlah Tanggungan Keluarga Terhadap Keputusan Wanita Untuk Bekerja

Hasil penelitian ditemukan terdapat pengaruh positif jumlah tanggungan keluarga terhadap peningkatan keputusan wanita untuk bekerja. Koefisien regresi jumlah tanggungan keluarga terhadap peningkatan keputusan wanita untuk bekerja, dimana nialai $\mathrm{t}$ hitung 0.309527 dan nilai $\quad($ prob $=0.7582$ $>0,05)$. Dengan $\mathrm{df}=60-6=54$ diperoleh $\mathrm{F}_{\text {tabel }}$ Sebesar 1,674 dari hasil di atas dapat dilihat bahwa jumlah tanggungan keluarga berpengaruh terhadap keputusan wanita bekerja.

Menurut Ratina (2007) yang menyatakan bahwa semakin banyak jumlah tanggungan keluarga, maka semakin tinggi curahan waktu tenaga kerja perempuan untuk bekerja. Bagaimana suatu rumah tangga 
mengatur siapa yang bersekolah, bekerja, dan mengurus rumah tangga bergantung pada jumlah tanggungan keluarga yang bersangkutan. Semakin banyak jumlah tanggungan keluarga, maka semakin tinggi pula probabilitas perempuan yang memutuskan untuk bekerja.

Jadi dapat disimpulkan berdasarkan hasil penelitian yang dilakukan di Kecamatan Koto Salak Kabupaten Dharmasraya bahwa jumlah tanggungan keluarga berpengaruh terhadap keputusan wanita untuk bekerja.

4. Pengaruh Pendapatan Suami Terhadap Keputusan Wanita Untuk Bekerja

Hasil penelitian di temukan terdapat pengaruh positif pendapatan suami terhadap peningkatan keputusan wanita untuk bekerja. Koefisien regresi pendapatan suami terhadap peningkatan keputusan wanita untuk bekerja, dimana nialai t hitung 1.072383 dan nilai $($ prob $=0.2885>0,05)$. Dengan $\mathrm{df}=60-$ 6=54 diperoleh $F_{\text {tabel }}$ Sebesar 1,674dari hasil di atas dapat dilihat bahwa pendapatan suami berpengaruh terhadap keputusan wanita bekerja.

Tingkat pendapatan suami memiliki peranan yang cukup penting dalam mempengaruhi keputusan perempuan berstatus menikah untuk bekerja. Sumarsono (2003) menjelaskan bahwa keluarga dengan penghasilan besar, relatif terhadap biaya hidup cenderung memperkecil jumlah anggota keluarga untuk bekerja, sedangkan keluarga yang biaya hidupnya relatif sangat besar pada penghasilannya cenderung untuk memperbanyak jumlah anggota untuk masuk dalam dunia kerja.

Jadi dapat disimpulkan berdasarkan hasil penelitian yang dilakukan di Kecamatan Koto Salak Kabupaten Dharmasraya bahwa pendapatan suami berpengaruh terhadap keputusan wanita untuk bekerja

5. Pengaruh Motivasi Terhadap Keputusan Wanita Untuk Bekerja

Hasil penelitian di temukan terdapat pengaruh positif motivasi terhadap peningkatan keputusan 
wanita untuk bekerja. Koefisien

regresi motivasi terhadap

peningkatan keputusan wanita untuk bekerja, dimana nialai $\mathrm{t}$ hitung 0.564968 dan nilai (prob $=0.5745>0,05)$. Dengan $\mathrm{df}=60$ $6=54$ diperoleh $F_{\text {tabel }}$ Sebesar 1,674dari hasil di atas dapat dilihat bahwa motivasi berpengaruh terhadap keputusan wanita bekerja

Motivasi sangat dibutuhkan untuk mencapai suatu tujuan seseorang, tanpa adanya motivasi seseorang akan merasa tidak semangat untuk melakukan segala kegiatannya termasuk keputusan wanita menikah untuk bekerja. Dari sudut motivasi tinjauan wanita bekerja dapat dikelompokkan menjadi dua kelompok yaitu kelompok pertama, wanita bekerja karena kebutuhan ekonomi yang kedua wanita bekerja bukan sematamata hanya alasan ekonomi akan tetapi karena alasan lainnya misalnya alasan agama dengan makna bahwa bekerja adalah ibadah.

Jadi dapat disimpulkan berdasarkan hasil penelitian yang dilakukan di Kecamatan Koto Salak Kabupaten Dharmasraya bahwa motivasi berpengaruh terhadap keputusan wanita untuk bekerja keputusan.

6. Pengaruh Tingkat Pendidikan, Umur, Jumlah Tanggungan Keluarga, Pendapatan Suami, dan Motivasi Terhadap Keputusan Wanita Untuk Bekerja

Berdasarkan hasil uji hipotesis yang dilakukan secara bersama-sama ditemukan bahwa variabel tingkat pendidikan, umur, jumlah tanggungan keluarga, pendapatan suami, dan motivasi berpengaruh signifikan terhadap keputusan wanita untuk bekerja

Analisis data dan pengujian hipotesis yang telah dilakukan untuk secara keseluruhan diperoleh nilai $F_{\text {hitung }} 63,379>F_{\text {tabel }} 2,14$ dan nilai signifikan $0,000<\alpha=0,05$. Dengan demikian dapat dikatakan bahwa tingkat pendidikan, umur, jumlah tanggungan keluarga, pendapatan suami, dan motivasi berpengaruh signifikan terhadap keputusan wanita untuk bekerja 


\section{KESIMPULAN}

Berdasarkan

kepada

permasalahan dan hasil analisis data yang telah dilakukan dapat disimpulkan sebagai berikut:

1. Peluang tingkat pendidikan yang semakin tinggi menyebabkan semakin kecil mempengaruhi peluang wanita bekerja di sektor pertanian dan perdagangan, sedangkan pada sektor jasa justru dengan semakin tingginya tingkat pendidikan menyebabkan tingginya peluang wanita untuk bekerja pada sektor jasa.

2. Peluang semakin muda umur maka semakin besar mempengaruhi peluang wanita bekerja di sektor pertanian, sedangkan semakin muda umur maka semakin kecil mempengaruhi wanita bekerja di sektor perdagangan dan jasa.

3. Peluang jumlah tanggungan keluarga yang semakin banyak mempengaruhi peluang wanita untuk bekerja di sektor pertanian, perdagangan dan jasa.
4. Peluang pendapatan suami yang semakin besar maka semakin kecil mempengaruhi peluang wanita bekerja di sektor pertanian, perdagangan. sedangkan semakin kecil pendapatan suami maka semakin tinggi mempengaruhi peluang wanita untuk bekerja di sektor jasa.

5. Peluang motivasi yang semakin kecil maka semakin kkecil pula mempengaruhi peluang wanita untuk bekerja di sektor pertanian, perdagangan dan jasa.

\section{DAFTAR PUSTAKA}

Arikunto. (2010b). Prosedur Penelitian Suatu Pendekatan Praktis, Edisi Revisi 2010,Cetakan Keempatbelas. Rineka Cipta.

Badan Pusat Statistik Propinsi Sumatera Barat.(2015). Statistik Ketenagakerjaan. Badan Pusat Statistik Propinsi Sumatera Barat.

Badan Pusat Statistik Propinsi Sumatera Barat.(2017). Statistik Ketenagakerjaan. Badan Pusat Statistik Propinsi Sumatera Barat.

MarianiMajid, f., \& handayani, h. R. 
Publish by: Library of STKIP PGRI Sumatera Barat

E-ISSN : 2775-5770

Vol. 1 No. 2 (Mei 2021) (263-272)

PENDIDIKAN

http://ejournal.stkip-pgri-sumbar.ac.id/index.php/horizon

(2012). Faktor-faktor yang mempengaruhi keputusan wanita bekerja ( studi kasus kota semarang ). 1, 1-9

Pratomo, Devanto Shasta. 2017.

Pendidikan dan Partisipasi Angkatan Kerja Wanita di Indonesia: Analisis Terhadap Hipotesis Kurva-U. Jurnal Ekonomi Kuantitatif Terapan, 10 (1), hal. 1-7.

Rade, and Hadi Sasana. 2013. "pendapatan suami, umur , tingkat pendidikan, curahan jam kerja pedagang

Riana, a., \& sasana, h. (2013). Pendapatan suami, umur, tingkat pendidikan, curahan jam kerja pedagang bumbon wanita ( studi kasus di pasar johar kota semarang ). 2(bps 2012), 1-13. 